
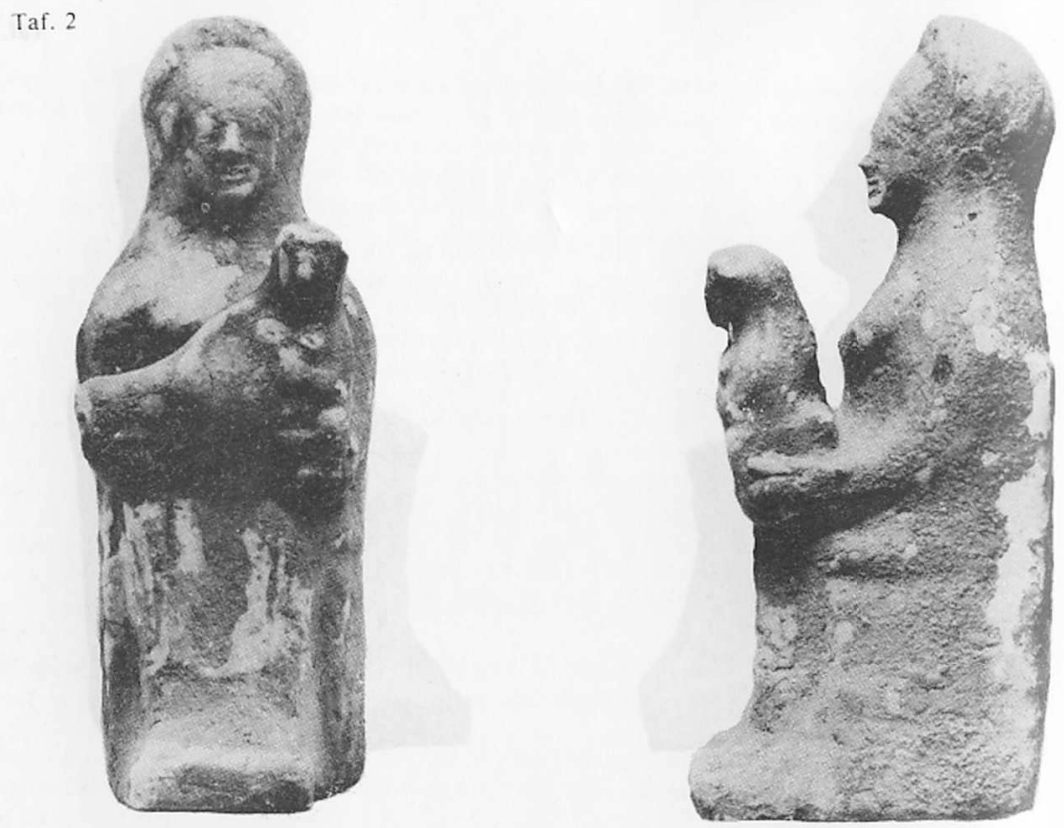

a

b
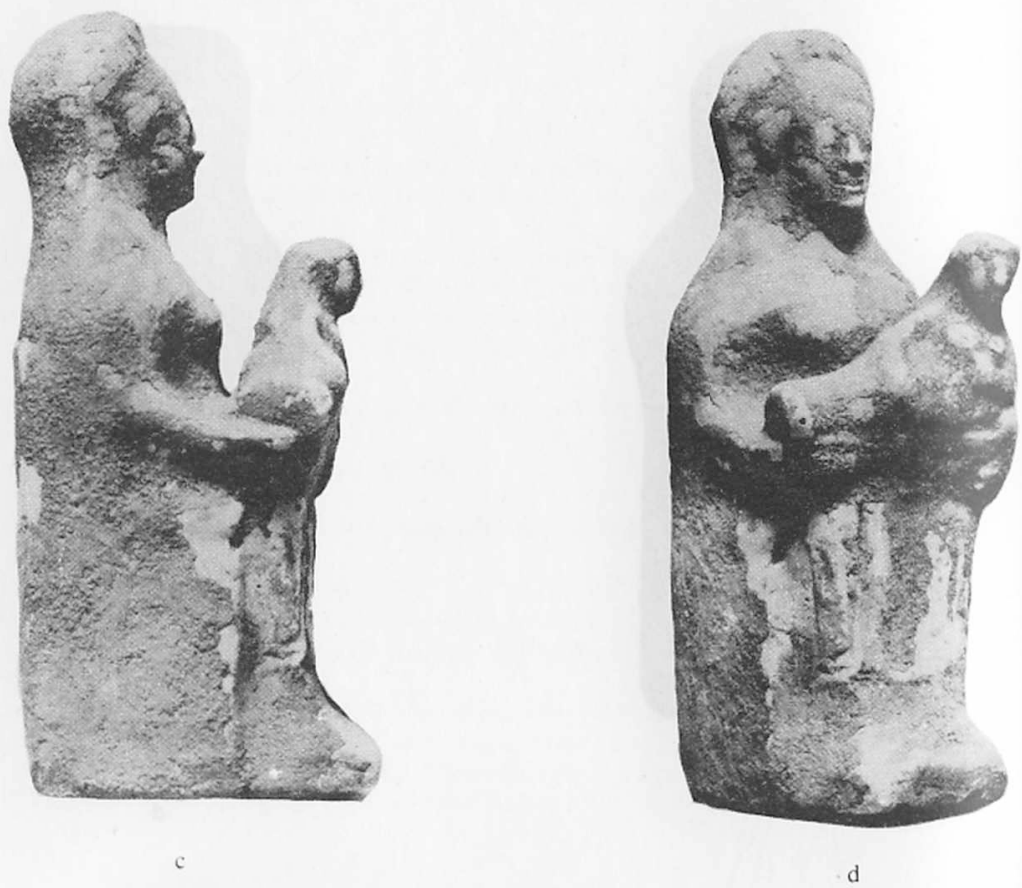


\section{HELLENISTIC GOLD COINS OF EPHESOS}

\section{Gilbert K.Jenkins}

Among the more notable coins of the later Hellenistic period is a series of gold staters of Ephesos. Some specimens are shown here on Plate A.1-3 and Plate B.4,6, enlarged to double size. On the obverse is the head of Artemis to the right, with her typical attribute, the bow and quiver, protruding from behind her neck. On the reverse we see the cult-statue of Artemis Ephesia, seemingly primitive in appearance but not necessarily so old as it seems: the famous image exists in a considerable number of reproductions in stone or metal, but mainly of Roman date and so much later than the first appearance of the image as a minute subsidiary symbol on the silver cistophori minted at Ephesos from about 175-166 B.C. onwards (1). As seen on the gold staters, most of the salient features of the cult image are shown in recognisable form - the polos headdress, a nimbus-like surround to the head (on the sculpture versions usually consisting of animal friezes flanking the head); the outstretched arms with fillets hanging from them, the stiff mummy-like sheath that encases the lower part of the figure; and the most curious feature of the image, the mass of so-called 'breasts' which on the coins seem to cover the whole torso (though on the sculpture versions the 'breasts' are mostly over the stomach, with a heavy wreath hanging from the neck above them). It has been recognised by modern scholars that these 'breasts' are in fact no such thing: some have interpreted them as eggs, some as dates, while most recently it has been suggested that there were, bull-sacrifices connected with the cult of the Ephesia and that the 'breasts' on the cult-image are in fact the testicles of sacrified bulls (2).

It is however not with the types of the gold staters that I am primarily concerned here, but with the question of chronology. These gold coins or Ephesos have, since the first comprehensive treatment of the Ephesian coinage by Barclay Head in 1880 (3), invariably been ascribed to the period of Mithradates VI's presence in western Asia minor, with his headquarters at Pergamon, during 88-84 B.C.So far as I can find, no one has disputed this theory, and following Head other scholars have assigned to this historical occasion not only gold coins of Ephesos but also of Erythrai, 
Miletos, Smyrna and Tralles (4). The occasion has often seemed a tempting one, and not least on account of a natural tendency to think of restricted issues of gold coin occurring either on grounds of emergency or of some other special occasion such as a city obtaining its freedom. However, positive evidence for the date of the Ephesian and other gold coins was in any case lacking until recently: nevertheless it exists, and I trust that this brief account of the matter may be of some interest to our honorand Prof. Ekrem Akurgal.

In the files of the British Museum, London, there has existed for some years a hand-drawn sketch of a gold coin of Ephesos, of the type already described. The original was observed in the Museum of Kayseri, and more recently a plaster cast of the specimen became available (here illustrated, Plate B.4). The obverse Artemis head, it is clear, was struck from the same die as a specimen in the British Museum (Plate B.6). But the most significant features of the Kayseri specimen are on the reverse, the details of which are clearly confirmed by the plaster cast. Below the cult-image of the Ephesia there is a Latin inscription giving the name of a Roman official C.A.IN.C.F. The official in question is not identifiable, but can be accurately dated; the same name in precisely the same form is also to be found on the reverse of a cistophoric tetradrachm (Plate B.5) of the mint of Ephesos during the Roman provincial era, bearing the date-mark I $\Gamma=$ year $13=122 / 1$ B.C. (5). Another point of connexion between the cistophorus and the gold stater is the caduceus symbol: this appears on the gold between the cult-image and the hanging fillett, on the right, and on the cistophorus above the bow-case between the snakes' heads.

From this coincidence we obtain a sure date for the gold stater in Kayseri -and a date incidentally well before the time of Mithradates VI. Linked by obverse die to this specimen there is another gold stater with a symbol torch in place of the caduceus: the time there is no inscription, but the torch symbol serves to make a connection with another cistophoric tetradrachm dated to the following year I $\Delta=$ year $14=121 / 0$ B.C. (6). Two further gold staters are connected with the two already mentioned, again using the same obverse die. These have different symbols: one a thymiaterion (the British Museum specimen, Plate B.6), the other a bee (7). These form no evident link to the cistophoric coinage, but on account of the same obverse die being used that was used for the staters of years 13 and 14, it seems clear that the coins with the thymiaterion and bee symbols must be at least of adjacent years. 
It is not my intention to try to give here any full account of the Ephesos gold series, but rather to mention two other small groups of staters which can be dated, either explicitly or by correspondance with the cistophori. It must be noted that a close and explicit correspondance with the cistophori -as in the case of the Kayseri coin- is unfortunately the exception rather than the rule. The cistophori follow a fairly regular system with dates and changing symbols, whereas the gold shows little sign of such a system and is clearly sporadic rather than continuous. Even on the cistophori there are certain symbols which tend to recur, such as the bee and stag, both clearly connected with the Artemis cult. These symbols also occur either singly or together on a number of gold specimens but hardly in such a manner as to give indications of date. However, of the further instances where we can date the gold staters, two of these themselves bear explicit date letters: year 2 (B) with symbol tripod (Plate A.2, British Museum), and year 9 ( $\Theta$ ) with symbols stag and bee (8). It is noteworthy here that the symbols on the cistophori of years 2 and 9 are different from those on the gold. On the other hand, at a much later phase there are gold staters with symbols that coincide with those on cistophori; a stater with symbol bow-in-bow-case tallies with the cistophorus of year 53 ( $\mathrm{N} \Gamma \quad)=82 / 1$ B.C. (9) a stater with symbol Artemis striding to right drawing arrow tallies with cistophorus of year $55(\mathrm{NE})=80 / 79$ B.C. $)(10)$; a stater with symbol owl-on-palm-branch (Plate A.3) tallies with cistophorus of year $56(N E)=79 / 8$ B.C. (11). Thus we can say that so far it is possible to identify gold staters for years 2 (=133/2 B.C.) and 9 (=126/5 B.C.); then for years 13 (=122/1 B.C.) and 14 ( $=121 / 0$ B.C.) with others adjacent; then after a long gap staters for years $53,55,56(=82 / 1-79 / 8$ B.C.). It is of course possible, and indeed likely, that other known gold issues could fill some of the years at present left empty, but the evidence for the moment seems indecisive. It is also of course quite possible that more specimens will be discovered, if we are to judge by the number that have appeared in commerce during the last decades. It is in any case intriguing, by contrast with the old 'Mithradatic' chronology, to find that on present evidence there seem to be no gold issues which could plausibly belong to the Mithradatic years (88-4 or perhaps rather 88-6), although the latest datable issues are close to that time, though in fact just after it ( $82 / 1-79 / 8$ B.C.). The cistophori on the other hand continue through the Mithradatic years uninterrupted.

Finally, we must not neglect to mention a group of the Ephesos gold which seems to stand by itself - if only because, instead of the shortened legend which is usual on other issues, here we have the full EФEIIRN The accompanying symbols consist of stag and bee (Plate A.1), or alternatively star, stag and bee, or alternatively bee alone (12). These 
various symbols are also to be found on the cistophori of the Roman era (Notably the bee in years 1 to 4); but there are hardly any correspondances which seem to give good indications of date. It would be possible of course to consider placing this group simply in year 1 (134/3 B.C.). At least the stylistic distinction of this group seems to preclude placing it anywhere in the middle of the Roman provincial era.If this group does not belong to year 1, we might even be justified on stylistic grounds in placing it earlier still, before the Roman era and during the Attalid period. The style of Plate A.1 seems even quite closely reminiscent of the Ephesian silver coins minted during the period of Ptolemaic domination (244-197 B.C.) (13). Admittedly there is at present no proof for such an early date for the Ephesos gold. But at the same time there is nothing impossible in such a concept -especially if we reconsider the chronology of the very rare gold staters of Tralles. We may recall that Tralles was, for Regling (note 4), a mint whose gold was of the Mithradatic years, and he makes an apparently strong case for this, on historical grounds. However, I doubt if it is correct. If we take due notice of the symbols which occur on the gold staters of Tralles (Plate B.7), it is at once clear that they tally with symbols from the Tralles series of pre-Roman cistophori. The Paris specimen (Plate B.7) has a symbol consisting a wreath above a thunderbolt: this occurs on the cistophori of $160 / 155$ B.C. (14). The Berlin specimen has the symbols star above eagle, and this corresponds to the cistophori of 140/135 B.C. (15). Thus it seems perfectly possible that a city of the Attalid kingdom, which was also a mint of the cistophoric coinage - such as both Ephesos and Tralles were - was not inhibited from striking gold coins of its civic type, even if its overlord the Attalid king issued no gold.

The main purpose of this short paper was to show that the connection between the gold coinage of Ephesos and the Mithradatic years must be discarded as an illusion. It is likely enough that the connection is equally illusory as regards the other mints for which it has been claimed, (though 1 would be inclined to leave the option open as regards Smyrna (16). The comparative extent of the gold issued at Ephesos during the II-I centuries B.C. though hardly equalling the late II century issues of Rhodes (17)- is finally a factor making it very unlikely that the coinage in question could be assigned to a mere couple of years (18). 
Notes

1) The starting date of the cistophoric coinage is placed by F.Kleiner, The Early Cistophoric Coinage (N.York 1977) at 166B.C.: O.M $\oint$ rkholm however, in Museum Notes 24, N.York 1979, 47ff. argues for a date close to $17 \xi$ B.C. For the cult-image as symbol, see Kleiner series 13 and 36.

2) L.Lacroix, Les Reproductions des statues sur les monnaies grecques, $176 \mathrm{ff}$. (with copious references to other literature, especially important for the monuments H.Thiersch, Artemis Ephesia I.Katalog der erhaltenen Denkmaler); C.Seltman, The Wardrobe of Artemis, NC 1952 1952, 33 ff.; G.Seiterle, Antike Welt 1979 Heft 3, 3-16.

3) B.V.Head, On the chronological sequence of the coins of Ephesus, NC 1880, $85 \mathrm{ff}$.

4) K.Regling, Zeitschrift für Numismatik 35, 1924, 265 ff.: S.Karwiese, PW Suppl. XII, 297 ff: G.K. Jenkins, Ancient Greek Coins $280 \mathrm{ff}$. (also mentioning gold of Abydos, Kyzikos, Teos, but with some caution as to the dates).

5) F.Kleiner, The dates cistophori of Ephesus, Museum Notes 18 (N.York 1972) 17 ff., esp.p. 25 no. 19 , plate XIII. 6 (Here Plate B.5, reverse only, double size).

6) F.Kleiner (as note 5) no. 20.

7) Leu Auktion Zurich 1975, 229 (bee symbol).

8) Gulbenkian, Lisbon: also Leu Auktion 18, Zürich 1977, 188.

9) Stater: Sotheby 1900 ('Late collector')348. Cistophorus: Kleiner (as note 5) no. 54 (year 53).

10) Stater: Berlin, Head Ephesus (as note 3) $5=$ Seltman (As note 2) pl.v.3. Cistophorus: Kleiner (as note 5) no. 56 (year 55).

11) Stater: Hess-Leu, Zürich 1963, 69. Cistophorus: Kleiner (as note 5) no. 57 (year 56).

12) Stag and bee, Plate A.1 -Paris. Star, stag and bee - Münzen u.Medaillen AG Basel 44, 1971, 15, do. 66, 1984, 243. Bee only - Leu Auktion 22, Zürich 1979, 132.

13) BMC Ionia, pl. XI. 1-2.

14) Waddington 5392. Cistophorus: Kleiner (as note 1) Tralles series 9.

15) Berlin, Regling (as note 4) 265. Cistophorus: Kleiner (as note 1) Tralles series 41.

16) Smyrna stater (Paris), Milne NC 1927 no. 344: stater (London), Jenkins (as note 4) no. 682-3, close in style to Smyrna tetradrachms of Milne NC 1927 period XV (c 85 B.C.)

- of the other mints whose gold coins have sometimes been assigned to the Mithradatic years, those of Teos and Erythrai have now been securely placed near 300 B.C.by P.Kinns (unpublished thesis). On Abydos, see Seyrig RN 1963, 20 note 2, suggesting a date c.188B.C.; on Kyzikos, Seyrig ibid., 19 note 2. For Miletos, BMC Ionia pl. XXII. 1-3; it seems probable that the date there indicated ('after 190') is reasonable, though elsewhere these coins too have been given to c.88B.C. Tralles, see above and notes 14,15 .

17) Hackens, Trésor hellénistique trouvé à Délos en 1964, BCH 1965, II, 503 ff. esp.p. 521 for listing of gold issues as a whole (to which there are now several addenda). 
18) As noted by P.R. Franke (in Munzen der Antike, Katalog 4, Gitta Kastner, Munich 1973, no. 110) Ephesos deserted Mithradates in 86 B.C.

\section{Additional note.}

The Ephesos gold staters are of Attic weight, theoretically and in former time c.8.60 gr. The Attic standard however, as Mørkholm has shown (Studia Paulo Naster oblata, Leuven 1982, 139 ff.), fell during the Hellenistic period with a tetradrachm of $16.80 \mathrm{gr}$. or less instead of $17.20 \mathrm{gr}$. It is not so clear what happened to gold, but we may well expect to find some fall here too. Thus the majority of the known specimens of the Ephesos gold weight between 8.40 and 8.50 gr.;those of Rhodes, for which see Hackens (as note 17), are only minutely heavier. - One Ephesos gold type is definitely of lighter weight, barely 5.50 gr. , presumably intended as an Attic octobol (e.g. former Jameson 2268, now Gulbenkian, Lisbon); it also has no legend. Yet the style of this type seems to me to connect it with the EQELI have suggested above may be the first, and possibly to be dated during the Attalid rather than the Roman period. The reasons for striking this denomination remain obscure: at least one can now rule out any relation as was once alleged by Mommsen (cf. Head, Ephesus p.69) to the heavy gold aureus of Sulla, of approximately twice the weight (e.g. $10.80 \mathrm{gr}$. ) and then deemed to have been struck in Asia Minor, perhaps at Ephesos. It has now been shown that the Sullan aurei are not eastern but south Italian (Crawford, NC 1964, 149-50: my thanks to Andrew Burnett for drawing my attention to this). 
Plate A
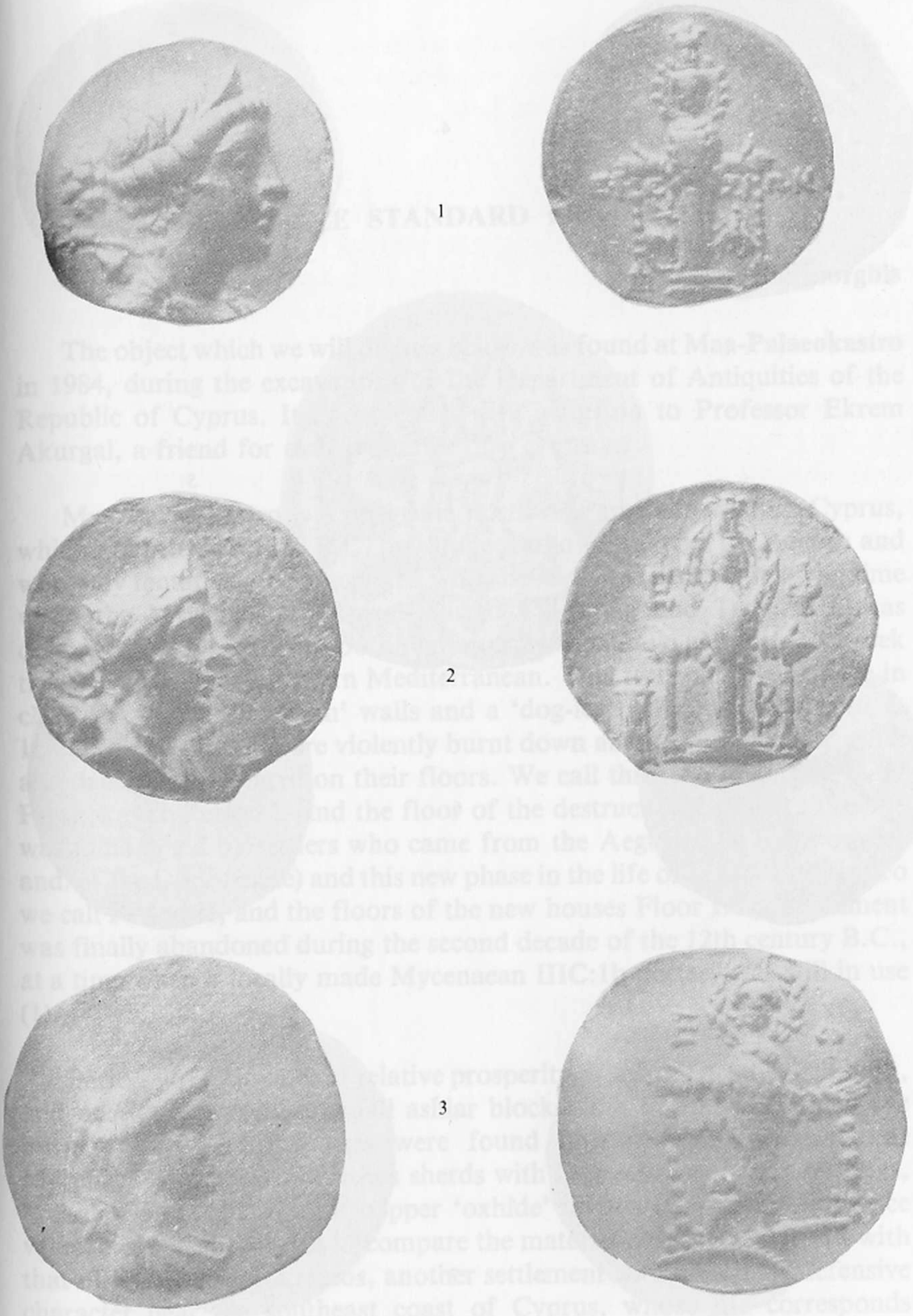
Plate B
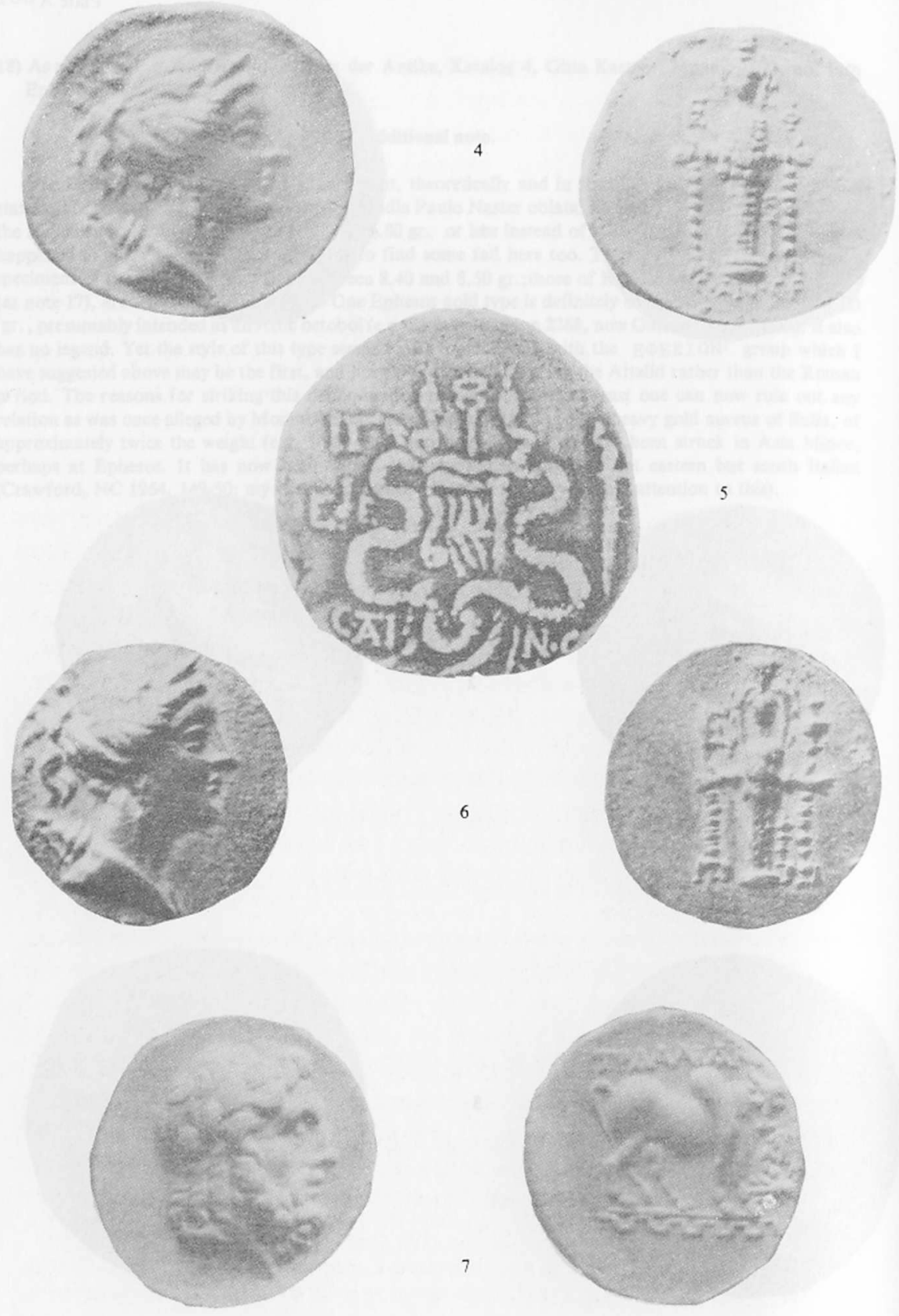


\section{A BRONZE STANDARD FROM CYPRUS}

Vassos Karageorghis

The object which we will discuss below was found at Maa-Palaeokastro in 1984, during the excavations of the Department of Antiquities of the Republic of Cyprus. It is dedicated with affection to Professor Ekrem Akurgal, a friend for over a quarter of a century.

Maa-Palaeokastro is a peninsula north of Paphos in western Cyprus, which was settled c.1230 B.C. by refugees who came from the Aegean and who may tentatively be associated with the 'Sea Peoples'. This is the time when the Mycenaean 'Empire' started collapsing and Troy VIIa was destroyed. Refugees from both regions may then have gone forth to seek their fortunes in the Eastern Mediterranean. This settlement, defensive in character, with 'cyclopean' walls and a 'dog-leg' gate, was destroyed c. 1200 B.C. Its houses were violently burnt down and a thick layer of ashes and débris accumulated on their floors. We call this first period of MaaPalaeokastro Period I, and the floor of the destruction Floor II. The site was reinhabited by settlers who came from the Aegean (the Peloponnese and/or the Dodecanese) and this new phase in the life of Maa-Palaeokastro we call Period II, and the floors of the new houses Floor I.The settlement was finally abandoned during the second decade of the 12th century B.C., at a time when a locally made Mycenaean IIIC:1b pottery was still in use (1).

Period I was a period of relative prosperity. The houses were well built, and one has a façade of small ashlar blocks with drafted edges. On the burnt floors of the houses were found important objects such as Mycenaean IIIB pottery, pithos sherds with impressions of cylinder seals, bronze tools, fragments of copper 'oxhide' ingots, fragments of faience vases, etc. One is tempted to compare the material culture of Period I with that of Pyla-Kokkinokremos, another settlement with a strongly defensive character near the southeast coast of Cyprus, whose life corresponds exactly to Period I at Maa-Palaeokastro (2). 